\title{
Science and Territory in Brazil: \\ The Brazilian army and the case of the Strategic Telegraph Commission of Mato Grosso to Amazonas (1907-1915)
}

\author{
Nísia Trindade Lima ${ }^{* *}$ \\ Dominichi Miranda de Sá
}

\begin{abstract}
:
During its years of activities, the Strategic Telegraph Commission earned a place in Brazilian history for its construction of communication infrastructure. Composed essentially of members of the military, the Commission provided services related to installation of telegraph lines and demarcation of Brazil's borders. Yet little attention has been paid to the scientific research carried out during voyages between 1907 and 1915, when Commission participants undertook the scientific exploration of the Brazilian territory, especially its geography. This paper shows how these exploratory voyages made a valuable contribution to Brazilian science and to policies aimed at the political and economic incorporation of the Brazil hinterlands.
\end{abstract}

Keywords: Territory; telegraph lines, scientific expeditions; the Brazilian Army; the Rondon Commission.

\section{Resumen}

Durante sus años de actividades, la Strategic Telegraph Commission ganó un lugar en la historia de Brasil por la construcción de su infraestructura de comunicaciones. Compuesta esencialmente por miembros de las fuerzas armadas, la Comisión prestó servicios relacionados con la instalación de líneas telegráficas y la demarcación de las fronteras de Brasil. Sin embargo, se ha prestado poca atención a la investigación científica llevada a cabo durante los viajes entre 1907 y 1915, cuando los participantes en la Comisión adelantaron la exploración científica del territorio brasileño, especialmente su geografía. En este trabajo se muestra cómo estos viajes de exploración hicieron una valiosa contribución a la ciencia brasileña y a las políticas dirigidas a la incorporación política y económica de las zonas del interior de Brasil.

\footnotetext{
${ }_{*}^{*}$ Artículo tipo 1: de investigación científica según Colciencias.

${ }^{* *}$ Researcher and professor with the Graduate Program in the History of Sciences and Health at the Casa de Oswaldo Cruz/Fiocruz, professor of sociology at the Universidade Estadual do Rio de Janeiro, and author of Um Sertão chamado Brasil (Rio de Janeiro: Revan/IUPERJ, 1999). E-mail: lima@coc.fiocruz.br. Address: Av. Brasil, 4036, $4^{\circ}$ andar, sala 401; Prédio da Expansão; Manguinhos; 20040-361 Rio de Janeiro, RJ; Brazil.

${ }^{* * *}$ Researcher and professor with the Graduate Program in the History of Sciences and Health at the Casa de Oswaldo Cruz/Fiocruz and author of A Ciência como Profissão (Rio de Janeiro: Editora Fiocruz, 2006). Email: dominichi@coc.fiocruz.br. Address: Av. Brasil, 4036, 4 andar, sala 401; Prédio da Expansão; Manguinhos; 20040-361 Rio de Janeiro, RJ; Brazil.
} 
Palabras claves: Territorio, líneas telegráficas, expediciones científicas, el Ejército brasileño, la Comisión Rondon.

\section{Introduction}

Scientific voyages and expeditions have become an important topic of analysis in the Brazilian social sciences and history in recent years. ${ }^{1}$ Scholars have endeavored to understand the images of "nature" and "population" portrayed by sages, physicians, sketch artists, painters, men of letters, scientists, members of the military, and naturalists from the colonial period through the twentieth century and how these images have helped to shape representations of social life in Brazil. Correspondence, reports, field diaries, and the books of voyagers dating back to Portugal's sixteenth-century discovery of Brazil, along with documents and visual representations especially from the turn of the twentieth century, have served as essential sources in the investigation of such topics as family, eating, clothing, work, gender, domestic life, sexuality, 'race', and cultural, social, and economic contrasts (Lima, 1999; Kury, 2009, 2001).

Until the nineteenth century, texts by naturalists, particularly those from abroad, were devoted primarily to inventories of the natural world and detailed descriptions of both collected specimens and interactions between human beings and the environment (Kury, 2009, 2001). At the turn of the twentieth century, travelers' reports-above all by Brazilians-began emphasizing the 'civilization' of Brazil, in other words, the incorporation and modernization of the country's various regions and particularly of the hinterlands, known as the sertão (pl. sertões). ${ }^{2}$

This shift in focus informed the organization of scientific voyages by the Brazilian government at the turn of the twentieth century. The voyages were essentially official modernization projects meant to expand the State's presence into the hinterlands in order to strengthen the territorial and political unity of Brazil at a time of numerous social transformations, like the 1888 abolition of slavery and the 1889 transition from monarchy to republic. Such projects to explore the economic potential of the Brazilian territory can be traced back to the Empire, which saw the creation of such bodies as the Scientific Exploration Commission (1856), Imperial

\footnotetext{
${ }^{1}$ This interest has been evidenced not only in books and academic theses, but also by the publication of specific issues of important periodicals in the area, devoted to the topic of these voyages. Further reflections of this interest are symposia and exhibits exploring the relations between science, field diaries, and representations of Brazil. We cite as important examples: "Viagens e Viajantes," Revista Brasileira de História, v. 22, no. 44, 2002; "Ciência e Viagens," História, Ciências, Saúde: Manguinhos, v. VIII, supplement, 2001; the 2000 colloquium "Science, Civilization, and Empire in the Tropics," sponsored by the Museu de Astronomia e Ciências Afins (MAST) and by the Universidade do Estado do Rio de Janeiro; and the exhibit "The Science of Travelers: nature, populations, and health in 500 years of interpretations of Brazil," sponsored by the Casa de Oswaldo Cruz/Fiocruz, likewise in 2000.

${ }^{2}$ Back then, the word "sertão" was used to refer to a variety of geographical regions, quite unlike today's predominant connotation of a semi-arid region. Sertão usually referred to areas lying some distance from government centers and modernizing projects. For a discussion of this point, see Lima, 1999.
} 
Geological Commission (1875), and São Paulo Geographic and Geological Commission (1886) (Figueirôa, 1997). The advent of the Republic boosted the number of projects and their stature, accompanying the greater involvement of proponents of the scientificist perspective-particularly of the positivist veinespoused by the majority of the era's intellectuals (Alonso, 1996; Carvalho, 1990; Barros, 1986; Lins, 1964).

Engaging more Brazilian scientists in exploratory expeditions was part of a process to reinforce national scientific production-the study of Brazilian topics by Brazilians (Lopes, 1999; Sá, Domingues, 1996); this goal was further reinforced with the creation and strengthening of such commissions and institutions as the Museu Nacional and the Instituto Histórico e Geográfico Brasileiro (Brazilian Institute of History and Geography). These exploratory expeditions were also part and parcel of an effort to incorporate the outlying regions of the territory with the rest of the country, including the development of transportation and communication infrastructure, especially the telegraph (Maciel, 2001, 1999).

Through an examination of the construction of the Brazilian telegraph network by the Comissão de Linhas Telegráficas Estratégicas de Mato Grosso ao Amazonas (Strategic Telegraph Commission of Mato Grosso to Amazonas), this paper shows how these exploratory voyages made a valuable contribution to Brazilian science and to policies aimed at the political and economic incorporation of the Brazil hinterlands.

\section{The Telegraph and National Integration}

'Sertão', 'settlement', 'civilization', and 'incorporation into nationhood' are recurrent terms in documents from scientific voyages in Brazil. The Brazilian government organized expeditions and commissions to locate suitable agricultural land, study efficacious settlement policies in the interior, carry out sanitation works, and build railroads and dams. These projects were presented as "civilizing missions" meant to incorporate the sertão. Such was the case, for example, of the medical-scientific expeditions undertaken by the Instituto Oswaldo Cruz and also of the Comissão Exploradora do Planalto Central do Brasil (Exploratory Commission on Brazil's Central Plateau), commonly known as the Cruls Commission in honor of its head, astronomer Louis Cruls.

Appointed when Floriano Peixoto was president of the Republic, the Cruls Commission was charged with demarcating lands for the construction of a new federal capital, as provided for in the 1891 Republican Constitution. The idea was to move the capital from the coastal city of Rio de Janeiro, then the country's main port and commercial, political, population, and intellectual hub, to a territorially central spot, so 'progress' would spread throughout interior regions (Vergara, 2006).

During its lifetime, from June 1892 to March 1893, the Cruls Commission did not limit itself to the geographic demarcation of Brazil's future capital. Its members also 
carried out a number of studies into the region's topography, hydrography, geology, vegetation, climate, diseases, and other features. Its reports called attention to the purported ignorance of the 'true' economic value of the interior and defended extending settlement of Brazil from the coast into the sertão. Although the capital was only to be moved much later, with the construction of Brasilia in 1960, the fact that this change remained on the Parliament's agenda of political debates indicates just how important the issue of incorporating the sertão was back then (Vieira, 2009)

The medical-scientific voyages sponsored by the Instituto Oswaldo Cruz (IOC) came at a time when the Institute had already made its name as a vital center for the Brazilian production of vaccines and immunizing serums and for experimental research. The IOC had earned its standing as a prominent scientific institute thanks to the successful public health campaigns it had waged in urban centers, like its fight against yellow fever in Rio de Janeiro in the early years of the twentieth century. These campaigns greatly furthered the medical prestige of its director, the scientist Oswaldo Cruz (Benchimol, 1999).

Thanks likewise to these campaigns, the Instituto Oswaldo Cruz began collaborating with a division for agricultural, commercial, and public works affairs within the Ministry of Industry, Roads, and Public Works. Led by the Institute's key scientists, these scientific expeditions initially traveled to the interior to observe activities meant to increase exports (then Brazil's economic base), regional development projects such as construction of railways, rubber extraction in the Amazon, and sanitary inspections at ports. Starting in 1910, the institute conducted its scientific voyages chiefly at the request of bodies within the Ministry of Roads, including the Superintendência de Desenvolvimento da Borracha, focused on the rubber industry, and the Inspetoria de Obras contra as Secas, responsible for antidrought efforts. Their objective was to assess the economic potential of rivers and to inventory the epidemiological and socioeconomic conditions in the Amazon and in Brazil's Northeast and Central-West. According to the physicians and scientists who took part in these voyages and expeditions-Oswaldo Cruz, Carlos Chagas, Arthur Neiva, and Belisário Penna, among others - the endemic diseases of the sertão were the biggest hindrance to the construction of Brazil's nationhood and the achievement of progress, thereby making sanitation campaigns and works an imperative (Castro-Santos, 1985, 1987; Lima e Hochman, 1996; Hochman, 1998; Lima, 1999, 2009; Kropf, 2009a, 2009b; Sá, 2009).

Around the same time as the Instituto Oswaldo Cruz voyages, expeditions were organized by the Strategic Telegraph Commission of Mato Grosso to Amazonas, commonly known as the Rondon Commission, because it was led by Cândido Mariano Rondon, a member of the army. Over a period of nearly two decades, the Rondon Commission undertook a series of exploratory expeditions that encompassed construction works on telegraph posts and stations as well as scientific research into the natural resources of the areas traveled. Scientific studies and projects in territorial integration were inseparable facets of the Commission's work (Sá, Sá, Lima, 2008). 
The expression "Rondon Commission" serves as an umbrella for various voyages by members of the Brazilian army's engineering and construction corps between 1907 and 1930, once again targeting incorporation of the Brazilian hinterlands. Their prime job was installation and maintenance of telegraph lines, but these trips also involved contact with indigenous societies and the demarcation and surveillance of Brazilian borders. And while they were busy hanging telegraph wires to open up communications between the country's urban centers and the sertão, members of the Commission engaged as well in scientific exploration of the territory, especially to learn about Brazil's geography.

Little has been studied of the Rondon Commission's scientific activities (Sá, Sá, Lima, 2008). To date, these pursuits have not received the same attention as the Commission's indigenist policies, which captured much attention when the first results were released in 1910 and 1920; indeed, they have continued as a point of focus even in more recent studies (Lima, 1995). The Commission is better known for giving birth to the Serviço de Proteção aos Índios (Indian Protection Service)or, as the story went in those days, for making contact with Indians who until then had been considered "wild cannibals" and had always been deemed responsible for the disappearance of earlier explorers of the Mato Grosso sertões. From its first days, the Rondon Commission gained fame in Brazil for allegedly having achieved the "peaceful incorporation into civilization" of a number of indigenous societies, while also protecting these same peoples from extermination during violent contacts with Amazon rubber tappers. ${ }^{3}$ Undertaken primarily during travels between 1907 and 1915, the Commission's scientific work meanwhile went unnoticed, notwithstanding its great import to such fields as cartography, botany, geology, zoology, anthropology, and the ethnography of indigenous and sertão populations (Sá, Sá, Lima, 2008). In the words of anthropologist Edgard RoquettePinto, in the preface to the fourth edition of his field diary as member of the Rondon Commission in 1912 (Rondonia): "Construction of the telegraph line was a pretext. Scientific exploration activities were everything” (Roquette-Pinto, 1938).

Since there are no comparative studies regarding other countries and construction of their communication infrastructure, we cannot affirm that the Rondon Commission was the only one in the world to embrace both telegraph construction works and scientific research. It can, however, be argued that the Commission's remarkable scientific accomplishments were not simply a natural consequence of the installation of telegraph lines and posts in a country of continental proportions, whose northern regions were practically unknown. As underscored earlier, the various government missions to incorporate Brazil's sertão regions at the turn of the twentieth century were characterized by the convergence of scientific research interests and the civilizing project. In the Brazil of those days, the Rondon Commission was unquestionably unique in how it conjoined scientific research, construction works on the telegraph network, and the incorporation of the sertão

\footnotetext{
${ }^{3}$ Missão Rondon: apontamentos sobre os trabalhos realizados pela Comissão de Linhas Telegráficas Estratégicas de Mato Grosso ao Amazonas/sob a direção do Coronel de Engenharia Cândido Mariano da Silva Rondon de 1907 a 1915. Brasília: Ed. Senado Federal, 2003.
} 
regions. This Commission can only be properly understood if we examine the trajectory of a key figure: Cândido Mariano da Silva Rondon (1865-1958).

\section{The Brazilian Military and Science}

Rondon is inarguably a mythical figure in the history of twentieth-century Brazil. In his homeland he is often remembered as "the patron of communications in Brazil" and "the explorer and civilizer of the sertões." Many of his biographers extol the diversity of his family background-he was supposedly a descendent of the colonial-period frontiersmen known as bandeirantes, of Portuguese and Spanish settlers, and of Terena, Bororo, and Guaná Indians. Yet his contribution to Brazilian science has never been properly analyzed.

Born in Mato Grosso to a relatively poor family and soon orphaned, like other young Brazilians back then he found the military offered him a chance at a professional future in a country where social ascension was limited. As a student at Rio de Janeiro's Praia Vermelha Military School, in 1890 he became a military engineer and received a bachelor's degree in mathematics and the physical and natural sciences. At the school, he taught astronomy and mechanics and adhered to positivism, which was to account for many of his stances, such as his view of the beneficent, utilitarian role of science and his protectionist, guardianship position towards the indigenous question.

Of the main scientificist theories from the latter half of the nineteenth century, positivism drew the most supporters in Brazilian intellectual circles, and the Military School in Rio de Janeiro was one institution where it held especially great sway. In the final three decades of the nineteenth century, the central lines of positivist thought were often discussed at the school. These included defense of the collective good as part of public life, the importance of social harmony to the expansion of social rights, and, above all, the definition of science as a moral compass, factor behind social transformation, an indispensable means to progress, and the foundation of political action (Carvalho, 1990; Barros, 1986).

At that time, positivism thus reigned as the 'intellectual climate' in a school that trained members of the Brazilian army, a fact evinced in the reformulation of course programs, where greater emphasis was placed on mathematics and the physical and natural sciences. In the 1880s and 1890s, positivist teachers and students at the Military School questioned the very mission of the Brazilian army (Diacon, 2006: 109; Castro, 1995; Lins, 1964: 295). Defending the ideals of universal brotherhood and altruism preached by French thinker Auguste Comte, father of positivism, followers at the school rejected the view of the army as a military corps trained and destined to fight wars. They believed officers should have technical and scientific training and should serve as agents of the country's material progress rather than as soldiers (Diacon, 2006). In Brazil, primarily among members of the military but also among other intellectual groups, positivism was taken up as a "civilizing political and scientific project" (Alonso, 1996). 
Although this 'scientific conception' of the Brazilian army's role did not enjoy a consensus at the Military School, particularly among officers, it should be noted that Rondon not only embraced it while he was a student there but during his military career became one of its most ardent defenders. ${ }^{4}$

Rondon's involvement in the construction of telegraph lines-in his words, "gauges of progress"-dates to the early days of his career as an officer in the Military Corps of Engineers. Starting under the Empire in the 1880s, the Army's battalion of engineers began working on the construction of railways and telegraph lines. When the Republic was proclaimed in 1889, the Comissão Construtora da Linha Telegráfica, or Telegraph Construction Commission, was founded; it was to link Mato Grosso to Goiás, with the central goal of achieving communication with isolated regions along the Brazilian borders with Paraguay and Bolivia. More precisely, it was meant to link existing telegraph lines in Rio de Janeiro, São Paulo, and Minas Gerais to those that would be erected between Cuiabá and the Araguaia River. Rondon joined this commission in 1891 under the leadership of Major Antonio Ernesto Gomes Carneiro; its work continued until 1898. Between 1900 and 1906, Rondon also participated in the construction of a telegraph line between Cuiabá and Corumbá. In his opinion, the posts, wires, and telegraph stations then installed would not only enable communication with Mato Grosso; an even broader and more thoroughgoing project was at stake, encompassing the country's key strategic points and making integration and surveillance possible (Sá, Lima, 2006).

To make this picture clearer, it should be explained that back then there were no overland routes or links between the Brazilian coast and the more distant regions of the Amazon, which could only be reached by a long river journey. The trip started in southern Brazil at the Prata River, traveling through Argentina, Uruguay, and Paraguay until reaching Mato Grosso. There is good reason why the Rondon Commission has been praised for finally rescuing Mato Grosso from its isolation and achieving the "territorial union of Brazil." (Diacon, 2006: 14, 31).

We should also mention that at the time of the Rondon Commission's first expeditions, the very notion of "Brazilian territory" was problematic. There were no detailed maps; little was known about geographical irregularities, which were incorrectly represented on maps; in terms of the country as a whole, there was scant information on the flow of rivers and topographical relief, among other geographical features; and Brazil's borders had yet to be wholly defined (Lima, 1999).

Against this backdrop, in 1907 Rondon took on what would be one of the most significant missions of his career and certainly the one that earned him definitive renown: heading the Strategic Telegraph Commission of Mato Grosso to

\footnotetext{
${ }^{4}$ On the criticisms and opposition suffered by positivist students and teachers at Rio de Janeiro's Military School who favored scientific education above military activities for officers in the Army, see Diacon, 2006, pp. 108-20; Castro, 1995.
} 
Amazonas, or Rondon Commission. The Commission's task was to link Rio de Janeiro to the territories of Amazonas, Acre (ceded to Brazil by Bolivia under a 1903 treaty), Alto Purus, and Alto Juruá, via the capital of Mato Grosso, Cuiabá. The ends of the line would be located in Cuiabá and Santo Antônio do Madeira, in the Amazon, which defined what was then known as the "great northeastern sertão." (Maciel, 1999; Biggio, 2000).

Construction of telegraph poles and lines between Cuiabá and Santo Antônio do Madeira ran from 1907 to 1915, when the Amazon region was reached. During its travels, the Commission stepped up its cartographic and geographic surveys of the Brazilian territory. The officers of the army's engineering and construction battalion were systematically joined by a series of naturalist scholars from the fields of botany, cartography, geology, zoology, and anthropology, principally from Rio de Janeiro's Museu Nacional, all working to map out and incorporate the sertão (Sá, Sá, Lima, 2008; Sá, Lima, 2006). In the Commission's 1915 report, Rondon, who had been promoted to lieutenant colonel in 1908, affirmed that the scientific exploration of the territory and its incorporation into the civilized world formed one and the same project. For him, geographical reconnaissance and findings and the study of Brazil's mineral riches, soil, climate, forests, and rivers should walk hand in hand with building telegraph lines, laying out roads into new frontier, designating sites for new settlements, planting the first crops, and establishing the first cattleraising sites (Sá, Lima, 2006).

The Commission's most notable accomplishments included the discovery of rivers, its travels through the Serra do Norte (now known as the state of Rondônia), the correction of cartographic inaccuracies, and contact with and study of indigenous societies. Rondon pointed up how these voyages yielded knowledge of the Brazilian territory and its geography. Such was the case of the discovery of the Juruena River; in his 1915 report, Rondon stated that until the Commission's travels, there were nothing but vague references to this river, such as those found in the text Cidade de Mato Grosso by nineteenth-century novelist Visconde de Taunay and also in cartographic documents from the colonial period (Sá, Sá, Lima, 2008; Sá, Lima, 2006). The discovery of the Dúvida River likewise became famous; a branch of the Madeira River, the Dúvida found a place on the map of Brazil following the Roosevelt-Rondon expedition, between December 1913 and March 1914. In his book Through the Brazilian Wilderness (1914), the former American president recorded his participation in this scientific voyage to the Amazon, organized by the Commission and by the American Museum of Natural History.

As we can see, scientific exploration and the goals of incorporating and settling Brazilian territory were deeply entwined. When the Commission was created, it was linked to both the War Ministry, of which the Brazilian Army was part, and the Ministry of Industry, Roads, and Public Works, whose directions and priorities were responsible for communication infrastructure works in Brazil. Following the project designed and proposed by the Engineering Club, the War Ministry wanted the Commission to see to it that Brazil's borders with Paraguay and Bolivia were 
accessible by land as well as via a large telegraph network that would allow the central government to keep in steady communication with these outlying areas of the country. The idea was to transform the farthest edges of Brazil into military outposts, with the main sites of military surveillance being Porto Murtinho and Bela Vista on the Paraguayan border and Corumbá and Coimbra on the Bolivian border. ${ }^{5}$ The Commission also answered to the Secretaria dos Negócios da Agricultura, Comércio e Obras Públicas, a section of the Ministry of Industry, Roads, and Public Works that was concerned with agriculture, commerce, and public works. Headed by the engineer Miguel Calmon du Pin e Almeida between 1906 and 1909, the Commission was supposed to study the people and natural riches of Mato Grosso and Amazonas and assess whether the soil in these regions would be suitable for planting and also evaluate the feasibility of constructing new communication routes. According to Calmon's instructions as published in the Diário Oficial (federal register), in March 1907, Rondon and his Commission were assigned mainly to "study the natural resources of the region traveled" through geological, geographic, botanical, and mineralogical investigations. ${ }^{6}$ Minister Calmon also ordered reports, with special emphasis on mapping of the region's extractive products, resulting in highly detailed documentation of the voyages (Sá, Sá, Lima, 2008).

Because of its military and civilian parentage, the Commission's purposes were concomitantly strategic, economic, and political. They also became scientific and 'civilizing' as the work unfolded, thanks to the role of positivism as a worldview held by the expeditions' military members.

\section{The scientific activities of the Telegraph Commission}

The Commission's scientific activities were not interrupted when it was transferred to the Ministry of Agriculture, Industry, and Commerce, created in 1906 but actually coming to life only in 1909 as a transformation of the Ministry of Roads' former Secretaria dos Negócios da Agricultura, Comércio e Obras Públicas. Having to answer to the Ministry of Agriculture seemed to imbue the Commission with an even more 'utilitarian' vision of knowledge, which accounts for the more systematic participation of scientists and naturalists as of 1909. An emphasis on applied science had in fact been a mark of this ministry since the time of the Empireunderstanding "applied science" as the need to put nature (a natural resource) at the service of man (Domingues, 1995).

The reports of the Strategic Telegraph Commission of Mato Grosso to Amazonas clearly demonstrate how the more immediate, pragmatic goals of achieving

\footnotetext{
${ }^{5}$ Missão Rondon: apontamentos sobre os trabalhos realizados pela Comissão de Linhas Telegráficas Estratégicas de Mato Grosso ao Amazonas/sob a direção do Coronel de Engenharia Cândido Mariano da Silva Rondon de 1907 a 1915. Brasília: Ed. Senado Federal, 2003, p. 34.

${ }^{6}$ Instruções pelas quais se deverá guiar o chefe da Comissão Construtora da Linha Telegráfica Estratégica de Mato Grosso ao Amazonas, organizadas de acordo com a letra b, do n. XXI do art. 35, da lei n. 1.617, de 30 de dezembro de 1906. Decisões do Governo N.19 - EM 4 DE MARÇO DE 1907. Aprova as instruções para o serviço da Comissão Construtora da Linha Telegráfica de Mato Grosso ao Amazonas.
} 
communications and incorporating the sertão regions dovetailed with the typical working style and concerns of naturalists. Their extensive descriptions of flora and fauna specimens, detailed geographic and geological descriptions accompanied by top-quality engraved plates, a glossary of terms from twenty indigenous languages, and other elements place the products of their work among the most valuable contributions to Brazilian science. Additional contributions were the photographs and films produced by the Commission, especially after the 1912 creation of a department devoted to film and photography (Seção de Cinematografia $e$ Fotografia). Headed by Major Luiz Thomaz Reis, its films included Ao Redor do Brasil (Around Brazil), which left a vital record of these voyages to the country's sertões (Sá, Sá, Lima, 2008; Sá, Lima, 2006).

Besides gathering, classifying, and cataloguing material, during the 1910s and 1920s the scientists of the Rondon Commission drew up detailed scientific reports, gave conferences, and published numerous texts for the general public on their voyages and findings, particularly about newly identified species. Alípio de Miranda Ribeiro, Arnaldo Blake Santana, and José Geraldo Kuhlmann, in zoology; Cícero de Campos and Euzébio de Oliveira in geology and mineralogy; Edgard RoquettePinto in anthropology; and Frederico Carlos Hoehne and João Geraldo Kuhlmann in botany were some of the noteworthy participants (Sá, Sá, Lima, 2008; Sá, Lima, 2006).

The Museu Nacional's collection was probably the foremost beneficiary of the Commission's work. Alípio de Miranda Ribeiro, one of the museum's most prominent zoologists and a member of the Commission, gave conferences in which he sharply criticized museum leadership for a lack of policies valuing the institute's collections and the work of its naturalists. For Ribeiro, the scientific lesson taught by Rondon was the best reply to Olavo Bilac, a famous Brazilian poet who declared the Museu Nacional an "ankylosed" institution-in other words, rigid, immobilized paralyzed (Sá, Sá, Lima, 2008; Ribeiro, 1945).

At conferences held at the Museu Nacional in 1916, Ribeiro compared the gathering of botanical, zoological, and anthropological collections over the institute's lifetime of nearly one hundred years (it was created in 1818) to the Commission's contributions in just eight short years. He underlined the diversity and volume of collected specimens in terms of yearly averages. In fields like botany, the Commission had sent 1,104 specimens per year on average compared to a previous figure of 530 . In zoology, the annual figure was 709 , compared to 593.14 before. In anthropology, the difference was even sharper: 422 against 11.85 (Ribeiro, 1945).

Miranda Ribeiro made it a point to stress how the Commission's scientific work was not limited to expanding the museum's collections. For instance, Commission reports offered information about discoveries and plentiful descriptions of new species of mammals, birds, insects, plants and medicinal vegetable substances, and freshwater fish and algae, along with illustrations in the form of engraved plates-in Ribeiro's words "magnificently drawn"-or of photographs, "many of 
them taken for the first time in their natural environment." Moreover, the material collected by the Commission made it possible to undertake a complete revision of Brazilian crustaceans of the family Argulidae and also furthered Museu Paulista director Hermann Von Ihering's work with mollusks (the Commission supplied him with data on 20 species, 3 of them new and very rare). Likewise in the field of zoology, a valuable collection of mosquitoes from the family Tabanidae was captured by Miranda Ribeiro and studied by Adolpho Lutz, then a scientist at the Instituto Oswaldo Cruz. In botany, the Commission provided data that was used in the research of Alberto José de Sampaio, author of "A Flora de Mato Grosso," a paper published in the museum's periodical Arquivos do Museu Nacional (Sá, Sá, Lima, 2008; Sá, Lima, 2006; Ribeiro, 1945).

Another distinguished naturalist taking part in the Commission's trips was the botanist Frederico Carlos Hoehne, who covered 7,350 kilometers of Mato Grosso's fields and forests in fairly straight lines, gathering botanical material and making phyto-physionomic observations. Years later, in Índice Bibliográfico e Numérico das Plantas Colhidas pela Comissão Rondon (1951, Bibliographic and numeric index of plants collected by the Rondon Commission), Hoehne himself was to remark that studying and mapping Mato Grosso was tantamount to developing the economy of all Brazil. Discovered to be home to an abundance of flora, the region was incredibly vast. Hoehne pointed out that entire European countries and people could fit inside it: Germany, France, Italy, Portugal, and Holland. For him, if Mato Grosso were readied for agriculture, it alone could produce enough to feed all Brazilians (Hoehne, Kuhlmann, 1951).

As we can see, the Commission's scientific activities offered an extraordinary opportunity for scientists engaged in fieldwork. The stereotyped naturalist had previously been a wise, stern German or Swede, indifferent to other aspects of life; rarely was he imagined to be an ordinary Brazilian. This image was very well portrayed in Brazilian writer Machado de Assis' fictional account The Botany Lesson. A statement by Miranda Ribeiro at one of his conferences at the Museu Nacional in 1916 also puts the matter in plain terms: "Once when I went to Rio Novo, I was introduced to a professor from the Ouro Preto School of Mines who was passing through. My introducer, the pharmacist Francisco de Paula Leopoldino de Araújo, [...] said: 'So-and-so, naturalist', to which the professor replied in a shocked voice, 'With that face? A naturalist?' And he quite rudely turned his back on me..." (Ribeiro, 1945: 71).

Rich in details, the reports by naturalists working with the Commission paint a vivid picture of the harsh conditions under which these exploratory trips into Brazilian territory were taken. The members of the Commission forged their way into the Amazon forest, facing high rates of malaria and periods of intense heat and fierce storms. They also grappled with countless problems transporting food and scientific research instruments, which were carried by pack animals who were usually unable to bear up under the long expeditions. The canoes that took the scientists into the rough waters of the rivers crisscrossing the Amazon region often capsized, not rarely killing their occupants and destroying the scientific material 
that had been collected. Given the rigors of these voyages, both naturalists and members of the military quite often asked to be released from the Commission.

\section{Conclusion}

By 1915, when the Commission had made the last of its voyages of scientific exploration, Rondon had been awarded a Livingstone Prize by the American Geographical Society, New York, in recognition of his standing as chief explorer of tropical lands. Mato Grosso had been equipped with 4,502 kilometers of telegraph lines and the Commission's members had surveyed an area of 50,000 square kilometers lying between the Juruena and Madeira rivers-a feat that would be deemed a veritable epopee. A general since 1919, and in 1955 named marechal-the highest rank in the Brazilian army-Rondon continued to receive a number of awards and tributes in Brazil and abroad during subsequent years. $\mathrm{He}$ was also nominated for the Nobel Peace Prize on more than one occasion. $\mathrm{He}$ carried out many other missions until his death in 1958, including the inspection of Brazil's borders from Guyana, Suriname, and French Guiana to Argentina between 1927 and 1930, the conservation of telegraph lines, and, under the Getúlio Vargas administration, leadership of the Brazil/Peru/Colombia Joint Commission, charged with easing border tensions among these countries. Over the course of his long career, he perhaps became best known for his work with the Indian Protection Service, created in 1910 together with the Service for the Protection of Indians and Localization of National Workers (Serviço de Proteção aos Índios e Localização dos Trabalhadores Nacionais, or SPILTN). The work of the Rondon Commission and of the Indian Protection Service exerted tremendous influence over the education and training of new generations of Brazilian anthropologists, such as the renowned Edgard Roquette-Pinto and, later, Darcy Ribeiro.

The goal of incorporating Brazil's far-off northeastern sertões may not have been fully realized by the Commission, and the utility of the telegraph lines was sharply questioned once wireless radiotelegraphy came on the scene in the 1920s. Nonetheless, as many Commission members have noted in papers, conferences, and books, the Commission's research and surveying efforts enriched the collections of Brazilian institutions like the Museu Nacional. They also played a decisive role in winning greater recognition of the work of Brazilian naturalists. Above all, these accomplishments helped expand knowledge of broad expanses of the Brazilian territory (Sá, Sá, Lima, 2008; Sá, Lima, 2006). As the zoologist Miranda Ribeiro affirmed in a 1908 paper published in the Brazilian journal Kosmos, the Rondon Commission wiped the term "unknown" off countless points on the map of Brazil (Ribeiro, 1945) ${ }^{7}$.

\footnotetext{
${ }^{7}$ The authors wish to thank Ingrid Fonseca Casazza and Leonardo Lusitano Mósso, who hold scholarships under CNPq's PIBIC program, as well as research assistant Ludmila Gama Pereira for their help in locating and researching documental sources.
} 


\section{BIBLIOGRAPHY}

\section{Documentary sources}

Hoehne, F. C.; Kuhlmann, J. G.. (1951). Índice bibliográfico e numérico das plantas colhidas pela Comissão Rondon. São Paulo: Secretaria de Agricultura.

Instruções pelas quais se deverá guiar o chefe da Comissão Construtora da Linha Telegráfica Estratégica de Mato Grosso ao Amazonas, organizadas de acordo com a letra b, do n. XXI do art. 35, da lei n. 1.617, de 30 de dezembro de 1906. Decisões do Governo N.19 - EM 4 DE MARÇO DE 1907. Aprova as instruções para o serviço da Comissão Construtora da Linha Telegráfica de Mato Grosso ao Amazonas.

Missão Rondon: apontamentos sobre os trabalhos realizados pela Comissão de Linhas Telegráficas Estratégicas de Mato Grosso ao Amazonas/sob a direção do Coronel de Engenharia Cândido Mariano da Silva Rondon de 1907 a 1915. (2003). Brasília: Ed. Senado Federal.

Ribeiro, Alípio de Miranda. (1945). A Comissão Rondon e o Museu Nacional. Rio de Janeiro: Ministério da Agricultura.

Roquette-Pinto Edgard, Rondonia, 4 ed. (1938). São Paulo, Rio de Janeiro, Recife, Porto Alegre: Companhia Editora Nacional.

\section{Bibliographic sources}

Alonso, Ângela. (1996). De Positivismo e de Positivistas: interpretações do positivismo brasileiro. BIB, no. 42, 2nd semester, pp. 109-34.

Barros, Roque Spencer Maciel de (1986). A llustração Brasileira e a idéia de Universidade. São Paulo: Convívio/Edusp.

Benchimol, Jaime Larry. (1999). Dos micróbios aos mosquitos. Febre amarela e a revolução pasteuriana no Brasil (Rio de Janeiro: Editora Fiocruz/Editora da UFRJ.

Bigio, Elias dos Santos. (2000). Cândido Rondon: a integração nacional. Rio de Janeiro: Contraponto; Petrobras.

Carvalho, José Murilo de. (1990). A Formação das Almas: o imaginário da República no Brasil. São Paulo: Companhia das Letras.

Castro, Celso. (1995). Os Militares e a República: um Estudo sobre Cultura e Ação Política. Rio de Janeiro: Jorge Zahar. 
Castro-Santos, Luiz Antonio de. (1985). O pensamento sanitarista na Primeira República: uma ideologia de construção da nacionalidade, Dados (28): 193-210.

Castro-Santos, Luiz Antonio de. (1987). Power, ideology and public health in Brazil. Ph.DThesis, Harvard University.

Diacon, Todd A. (2006). Rondon: o marechal da floresta. São Paulo: Companhia das Letras.

Domingues, Heloisa Maria Bertol. (1995). Ciência, um caso de política: as relações entre as ciências naturais e agricultura no Brasil Império. Tese (Doutorado) Faculdade de Filosofia, Ciências e Letras, Universidade de São Paulo, São Paulo.

Figueirôa, Silvia. (1997). As ciências geológicas no Brasil: uma história social e institucional, 1875-1934. São Paulo: Hucitec.

Hochman, Gilberto. (1998). A era do saneamento. As bases da política de saúde pública no Brasil. São Paulo: Hucitec/ANPOCS.

Kropf, Simone Petraglia. (2009a). Doença de Chagas, doença do Brasil: ciência, saúde e nação (1909-1962). Rio de Janeiro: Ed. Fiocruz.

Kropf, Simone Petraglia. (2009b). Carlos Chagas e os debates e controvérsias sobre a doença do Brasil (1909-1923). História, Ciências, Saúde-Manguinhos, v. 16 , p. 205-227,

Kury, Lorelai. (2009). "Explorar o Brasil: o Império, as Ciências e a Nação" In Kury, Lorelai. (Org.). Comissão Científica do Império. Rio de Janeiro: Andrea Jakobsson Estúdio, pp. 19-49.

Kury, Lorelai. (2001). Viajantes-naturalistas no Brasil oitocentista: experiência, relato e imagem. História, Ciências, Saúde-Manguinhos, v. VIII, n. Suplemento, pp. 863-880,

Lima, Antonio Carlos de Souza. (1995). Um grande cerco de paz: poder tutelar, indianidade e formação do Estado no Brasil. Petrópolis: Vozes.

Lima, Nísia Trindade. (2009). Uma brasiliana médica: o Brasil Central na expedição científica de Arthur Neiva e Belisário Penna e na viagem ao Tocantins de Julio Paternostro. História, Ciências, Saúde-Manguinhos, v. 16, p. 229-248.

Lima, Nísia Trindade. (1999). Um sertão chamado Brasil. Intelectuais e representação geográfica da identidade nacional. Rio de Janeiro: Iuperj/Revan.

Lima, Nísia Trindade e Hochman, Gilberto. (1996). "Condenado pela raça, absolvido pela medicina: o Brasil redescoberto pelo movimento sanitarista da 
Primeira República" In Maio, Marcos Chor; Santos, Ricardo V. Raça, ciência e sociedade. Rio de Janeiro: Fiocruz/Centro Cultural do Banco do Brasil.

Lins, Ivan. (1964). História do Positivismo no Brasil. São Paulo: Companhia Editora Nacional.

Lopes, Maria Margaret. (1999). Aspectos da institucionalização das ciências naturais no Brasil no século XIX, Quipu: Rev. Latino Am. de Historia de las Ciencias y la Tecnologia, v. 12, no. 2, pp. 217-30.

Maciel, Laura Antunes. (2001). Cultura e tecnologia: a constituição do serviço telegráfico no Brasil. Revista Brasileira de História, São Paulo, v.21, n.41, p.127144.

Maciel, Laura Antunes. (1998). A nação por um fio: caminhos, práticas e imagens da Comissão Rondon. São Paulo: Educ; Fapesp.

Sá, Dominichi Miranda de. (2009). Uma interpretação do Brasil como doença e rotina: a repercussão do relatório médico de Arthur Neiva e Belisário Penna. História, Ciências, Saúde-Manguinhos, v. 16, p. 183-203.

Sá, Dominichi Miranda de; Sá, Magali Romero; Lima, Nísia Trindade. (2008). Telégrafos e Inventário do Território no Brasil: as atividades científicas da Comissão Rondon (1907-1915). História, Ciências, Saúde-Manguinhos, v. 15, p. 779-810.

Sá, Dominichi Miranda de; Lima, Nísia Trindade. (2006). No rastro do desconhecido. Revista de História da Biblioteca Nacional, Rio de Janeiro, v. 11, p. $18-23$.

Sá, Magali Romero, Domingues, Heloísa Maria Bertol. (1996). O Museu Nacional e o Estudo das Ciências Naturais no Brasil no Século XIX, Revista da Sociedade Brasileira de História da Ciência, v. 15, pp. 79-88.

Vergara, Moema Rezende (2006). Ciência e História no Relatório da Comissão Exploradora do Planalto Central na Primeira República. História, Ciências, SaúdeManguinhos, v. 13, p. 909-926.

Vieira, Tamara Rangel (2009). No coração do Brasil, uma capital saudável. A participação dos médicos e sanitaristas na construção de Brasília (1956-1960). História, Ciências, Saúde-Manguinhos, v. 16, p. 289-312.

Recibido: Febrero 15 de 20111

Aprobado: Mayo 9 de 2011 
